\section{CURRENT RESEARCH IN LAND, WATER, AND AGROECOSYSTEMS: ASABE JOURNALS 2017 YEAR IN REVIEW}

\author{
K. R. Douglas-Mankin
}

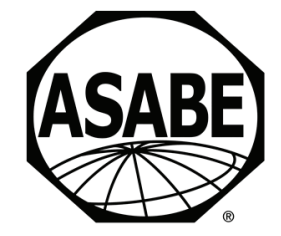

Invited Review

\begin{abstract}
This article highlights current research into land and water resources, agroecosystems, and agricultural production systems published by the Natural Resources and Environmental Systems (NRES) community of ASABE journals (Transactions of the ASABE and Applied Engineering in Agriculture) in 2017. Context, scope, and key results of the published articles are reviewed and perhaps more importantly areas for increased research attention are recommended. This article describes experimental and modeling advances in hydrology, agroecosystems, climate change effects, soil erosion, agricultural irrigation, agricultural drainage, forest resource management, livestock systems, natural treatment systems, international water issues, and water quality topic areas. Three special collections were published (International Watershed Technology, Crop Modeling and Decision Support for Optimizing Use of Limited Water, and Advances in Drainage). Other focal areas included 14 articles relating to livestock waste management, 13 concerning irrigated agricultural systems, 8 addressing climate change effects on land, water, and agroecosystems, and 16 on various aspects of soil erosion measurement and modeling. Building on the articles reviewed from 2017 and toward a vision of future agroecosystems research, the NRES community of ASABE journals strives to expand its role in making new knowledge accessible to sustain agricultural and natural systems in a changing world. With this goal in mind, recommendations for future research needs are proposed with an emphasis on increased application of remote sensing data to agroecosystems research, improved assessment of agroecosystem resiliency and vulnerability to land and climate change, development of integrated models of agroecosystem services, meeting stubborn water management challenges in agricultural production systems, and focusing on publishing fully reproducible model results.
\end{abstract}

Keywords. Agriculture, Climate change, Composting, Crop models, Crop water use, Crop yield, Drainage, Drought, Environment, Field experimentation, Food, Forest, Greenhouse gas emissions, Hydrologic modeling, Hydrology, Irrigation, Livestock, Manure management, Modeling, Natural resource, Soil erosion, Wastewater treatment, Watershed, Water quality, Water use.

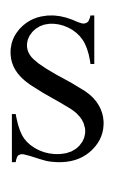
ustainability of land, water, and agroecosystem resources is the central challenge of this generation of natural resources, agricultural, and environmental scientists and engineers. Global challenges include food and water security; water use, availability, and quality; the food, energy, water systems nexus; agroecosystem sustainability; and greenhouse gas emissions. All demand urgent attention by the international research community, especially in the context of growing human populations, nonstationary climate, and limited land and water resources. Research into new understanding of and adaptable solutions to these challenges at local to global scales is needed. The Natural Resources and Environmental Systems (NRES) com-

Submitted for review in February 2018 as manuscript number NRES 12821; approved for publication as an Invited Review by the Natural Resources \& Environmental Systems Community of ASABE in July 2018.

Mention of company or trade names is for description only and does not imply endorsement by the USDA. The USDA is an equal opportunity provider and employer.

The author is Kyle R. Douglas-Mankin, Supervisory Research Hydrologist, USGS Climate and Surface Processes Unit, New Mexico Water Science Center, 6700 Edith Blvd. NE, Albuquerque, NM 87113; phone: 505-830-7916; e-mail: krdmankin@gmail.com. munity of the American Society of Agricultural and Biological Engineers (ASABE) publishes leading research addressing these and other issues faced by local communities and our global society, as we seek sustainability with finite land, water, and agroecosystem resources.

In 2017, 76 articles were published in Transactions of the ASABE and 22 in Applied Engineering in Agriculture by 379 authors across all topic areas of the NRES community. Three special collections were published: 6 articles in International Watershed Technology III (Tollner and Douglas-Mankin, 2017), 15 articles in Crop Modeling and Decision Support for Optimizing Use of Limited Water (Kisekka et al., 2017), and 14 articles in Advances in Drainage (Strock et al., 2018; 4 articles published in Applied Engineering in Agriculture, 2017, and reviewed herein, and the remaining 10 articles published in Transactions of the ASABE, 2018). Other focal research areas included 14 articles on livestock waste management, 13 on irrigated agricultural systems, 8 on climate change effects on land and water resources, and 16 on various aspects of soil erosion measurement and modeling.

The present article highlights the research published by ASABE's NRES community in 2017 and describes the context, scope, and key results for each study. The studies are 
organized by topic area and cross-referenced when appropriate. Finally, future research needs are discussed to extend the current body of knowledge toward a more comprehensive scientific and engineering research basis for sustainability of land, water, and agroecosystems.

\section{HYDROLOGY}

\section{HYDROLOGIC MODELING}

Numerous modeling studies published in 2017 (table 1) expanded ASABE's extensive publication history in watershed and field-scale hydrologic and water quality modeling (e.g., Muñoz-Carpena et al., 2006; Douglas-Mankin et al., 2010; Tuppad et al., 2011; Moriasi et al., 2012, 2015; Harmel et al., 2018). Many studies applied hydrologic and water quality models to simulate specific constituents (e.g., soil erosion, water quality) or support specific objectives (e.g., climate change effects, drought quantification, forest resource management) and are discussed throughout this review. Two studies were not tied to specific models but rather advanced hydrologic modeling research more broadly. Barnhart et al. (2017) introduced a multi-objective evolutionary sensitivity handling system (MOESHA) and demonstrated that, while computationally expensive, it can differentiate between impactful and non-impactful parameters, assess parameter uncertainty, and achieve excellent calibration results. Linhoss et al. (2017) demonstrated the importance of using multiple objective functions and selecting the prior probability distribution function (PDF) to represent parameter uncertainty for model sensitivity and uncertainty analyses; they found that the choice of objective functions and prior PDFs impacted the ranking of important parameters and inputs in the Mississippi Irrigation Scheduling Tool (MIST).

\section{Hydrologic Monitoring}

A set of 12 field-scale (15 m wide, $27 \mathrm{~m}$ long) lysimeters were constructed in central Pennsylvania with earthen berms to isolate and collect overland flows and with subsurface tile drains to collect shallow lateral flows (Duncan et al., 2017).
Clear patterns were observed in surface and subsurface flows, but the observed variability may have resulted from bypass flow. This study illustrated both the opportunities and limitations of field-scale lysimeter research.

\section{Agroecosystems \\ Evapotranspiration AND SoIL Moisture}

In an introduction to a collection of 12 studies on evapotranspiration (ET), Amatya et al. (2016) identify several areas for future research, including enhancement of thermal remote sensing-based technology for regional and global modeling and better characterization of the complex ecohydrological soil-vegetation-atmosphere feedbacks of ET to improve understanding of crop water use dynamics and response to changing climate; several 2017 articles address these issues. Remote sensing ET estimates using METRIC demonstrated the potential to use irrigation to increase crop ET as a flood-mitigation strategy (Büyükcangaz et al., 2017). Other simulation studies of crop ET are discussed in the sections on crop modeling (DeJonge and Thorp, 2017; Marek et al., 2017) and climate change effects (Mishra et al., 2017; Tatsumi, 2017).

\section{CROP YIELDS AND WATER USE}

Spatial and temporal variability of corn and soybean production was assessed at the county-scale in the U.S. Great Plains (Kukal and Irmak, 2017). Increasing trends were found for grain yield, precipitation use efficiency, and crop water productivity; interannual variations indicated opportunities for production system improvements. Zhao et al. (2017) found that available water-holding capacity (AWC) was an effective metric for delineating zones for variablerate irrigation, and that differences in AWC influenced corn and winter wheat yields and water productivity in an alluvial flood plain in China. Alfalfa yield and crop water-use efficiency in a semi-arid region of China had greater response to irrigation application prior to the first cutting and progressively less response to applications prior to second and third cuttings (Li, M. et al., 2017); irrigation also affected relative

Table 1. Summary of modeling research published in 2017 and discussed herein. The hydrologic and water quality modeling category includes water, sediment, nutrient, and pesticide fate and transport at field to watershed scales. The crop modeling category includes studies simulating crop growth or yield, either as stand-alone models or as submodels within hydrologic and water quality models.

\begin{tabular}{|c|c|c|}
\hline Category & Model & Reference \\
\hline \multirow{7}{*}{$\begin{array}{l}\text { Hydrologic and } \\
\text { water quality } \\
\text { modeling }\end{array}$} & AnnAGNPS & Yasarer et al., 2017 \\
\hline & APEX & Van Liew et al., 2017 \\
\hline & REMM & Tilak et al., 2017 \\
\hline & RHEM & Al-Hamdan et al., 2017; Lisenbee et al., 2017 \\
\hline & SWAT & $\begin{array}{l}\text { Lee, S. et al., 2017; McDaniel et al., 2017a, 2017b, 2017c; Mittelstet et al., 2017; } \\
\text { Muenich et al., 2017; Renkenberger et al., 2017; Wallace et al., } 2017\end{array}$ \\
\hline & USLE and WEPP & Lang et al., 2107; Svendsen et al., 2017; Wu et al., 2017 \\
\hline & WEPP and USLE & $\begin{array}{l}\text { Grace III, 2017; Lang et al., 2107; Lisenbee et al., 2017; Srivastava et al., 2017; } \\
\text { Wang, L. et al., 2017; Wu et al., } 2017\end{array}$ \\
\hline \multirow[t]{9}{*}{ Crop modeling } & APSIM & Araya et al., 2017; Whitbread et al., 2017 \\
\hline & AquaCrop & Espadafor et al., 2017; Linker and Kisekka, 2017; Wibowo et al., 2017 \\
\hline & DSSAT-CSM-CERES-Beet & Anar et al., 2017 \\
\hline & DSSAT-CSM-CERES-Maize & $\begin{array}{l}\text { DeJonge and Thorp, 2017; Fang et al., 2017a, 2017b; Joshi et al., 2017; } \\
\text { Linker and Kisekka, 2017; Marek et al., 2017; Sharda et al., } 2017\end{array}$ \\
\hline & DSSAT-CSM-CERES-Wheat & Adhikari et al., 2017; DeJonge and Thorp, 2017; Fang et al., 2017a \\
\hline & DSSAT-CSM-CROPGRO-Cotton & Adhikari et al., 2017; Thorp et al., 2017 \\
\hline & EPIC & Rasche and Taylor, 2017; Tatsumi, 2017 \\
\hline & RZWQM & Anar et al., 2017; Fang et al., 2017a, 2017b; Linker and Kisekka, 2017; Liu et al., 2017 \\
\hline & SWAT & Feng et al., 2017 \\
\hline
\end{tabular}


feed value but not crude protein.

In a soilless culture with low water-holding capacity, water must be applied frequently and precisely. A low-cost irrigation control system, developed and tested for use with soilless culture systems on commercial farms, was found to accurately control irrigation amount and timing while also matching a target leaching fraction (Rodríguez et al., 2017).

\section{Drought QuanTIFICATION}

A crop-specific, weekly drought index was developed from five factors: 35 -day total precipitation relative to the site normal, temperature and soil moisture stresses using crop-specific thresholds, transpiration using actual relative to daily maximum ET, and cumulative biomass production relative to the site normal (McDaniel et al., 2017a). The introduced drought index, populated with climate data and SWAT-simulated biomass production, soil moisture, and ET for cotton in western Texas, was found to be a good indicator of soil-moisture-related yield (McDaniel et al., 2017b). The drought index was then tested using short-term (two-week) weather forecasts compared to actual data and found to have satisfactory performance (McDaniel et al., 2017c), indicating potential for informing agricultural water management decision-making, such as irrigation timing.

\section{CROP MODELING}

Crop models play an important role in optimizing agricultural water use to meet the challenges of changing weather and climate, increasing population, and depleting groundwater. The crop models assessed, applied, or enhanced in 2017 are summarized in table 1. DSSAT-CERESMaize was found to adequately simulate corn leaf area index (LAI), ET, soil moisture, and yield response for two droughttolerant corn hybrids in Texas for fully irrigated treatments but was less reliable for limited irrigation treatments (Marek et al., 2017). In eastern Canada, Joshi et al. (2017) found that DSSAT-CERES-Maize adequately simulated corn and biomass yield, LAI, and soil organic $\mathrm{C}$ but not soil moisture or soil nitrate in continuous corn under conventional tillage, reduced tillage, and no tillage with two levels of residue management.

Timing of irrigation was critical for increasing wheat yields in Kansas (Araya et al., 2017); the researchers used a validated APSIM model to demonstrate that a limited irrigation application of $100 \mathrm{~mm}$ applied at booting and heading provided the highest water use efficiency as well as the greatest increases in yield compared to rainfed (dryland) production. A modification of SWAT to allow simulation of maximum annual LAI (instead of a static value) during establishment of switchgrass and Miscanthus perennial grasses resulted in more realistic simulation of LAI values and biomass yields (Feng et al., 2017). A new generic pest submodel was developed for EPIC that simulated pest pressure (for insects, fungi, and weeds), pesticide application, and crop response (Rasche and Taylor, 2017); test cases using cotton, maize, potatoes, soybeans, and wheat crops resulted in reasonable comparisons between simulated and reported mean and spatial distributions of pesticide application rates.

Fourteen articles from the ASABE 2016 Annual International Meeting comprised the Crop Modeling and Decision
Support for Optimizing Use of Limited Water collection, as introduced and reviewed by Kisekka et al. (2017) and highlighted here. One study developed a new dual-crop-coefficient approach to simulate the effects of both soil water and basal crop response on ET (DeJonge and Thorp, 2017), and a second study successfully adapted the improved model for real-world, in situ water management (Thorp et al., 2017). Several other studies applied crop models for irrigation scheduling, including an optimization of wheat and maize irrigation scheduling in China (Fang et al., 2017a), a novel model-based optimization of deficit irrigation in the U.S. High Plains (Linker and Kisekka, 2017), a schedule that used a water-stress factor to trigger irrigation, leading to water conservation and increased yields (Liu et al., 2017), and an assessment of supplemental irrigation in the Mississippi Delta (Tang et al., 2018). Two studies assessed crop model development and parameterization: Espadafor et al. (2017) used high-quality lysimeter yield and ET data from California to enhance AquaCrop model parameterization for dry beans, and Anar et al. (2017) parameterized, calibrated, and validated the CERES model for sugarbeet. Important improvements to crop coefficients and algorithms were made to reflect water, nutrient, and biomass-yield interactions for a new maize hybrid (Fang et al., 2017b). Two studies used crop models for soil and water management: one demonstrated no reduction in cotton yield or soil water from a winter-wheat cover crop in Texas (Adhikari et al., 2017), and another demonstrated enhanced simulation of soil-water storage and wheat yields using field-based, rather than labbased, estimates of crop lower-limit and drained upper-limit in low-rainfall cropping systems of southern Australia (Whitbread et al., 2017). A modeling analysis of irrigated corn production in Kansas found that risk-averse irrigation strategies were sensitive to well capacity and soil type and may substantially increase total water use (Wibowo et al., 2017). Two regional studies using crop models to assess climate change effects (Sharda et al., 2017; Tatsumi, 2017) are discussed in the next section.

\section{Climate Change Effects on Land, WATER, AND AGROECOSYSTEMS}

Projected climate change is expected to negatively affect food production and water resource availability and quality, and innovative strategies are needed to mitigate those adverse impacts (Chaubey et al., 2016). Climate change effects and mitigation strategies were each assessed by several studies in 2017.

\section{Assessment of Climate Change Effects}

Climate change effects were assessed in five studies. Wallace et al. (2017) found that future climate resulted in significant $9 \%$ to $22 \%$ decreases in surface flow, significant $20 \%$ to $26 \%$ increases in subsurface tile flow, significant (but small) increases in sediment, and no significant differences in atrazine, soluble $\mathrm{N}$, total $\mathrm{N}$, and total P losses among the four subwatersheds simulated by using SWAT in Indiana, as well as no evidence of impact from subwatershed size. Mishra et al. (2017) projected an increased frequency, 
sever-ity, and spatial extent of droughts in Alabama and Georgia for future climates on the basis of changes to a standardized precipitation index and a standardized precipitation-ET index. Using the EPIC crop model, Tatsumi (2017) found shortened growing season, decreased water use efficiency, increased ET, and reduced corn yield in almost all regions of the U.S., despite the potential positive yield effect from rising $\mathrm{CO}_{2}$. Kukal and Irmak (2017) demonstrated the long-term (32-year) response of corn and soybean to historical climate in the U.S. Great Plains on the basis of yield, precipitation use efficiency, and crop water productivity, whereas Sharda et al. (2017) demonstrated that both soil and climate variability in Alabama are important factors to consider in crop-climate impact studies.

\section{Assessment of Climate Change Mitigation}

Mitigation of climate effects was assessed in three studies. A study in the Coastal Plain of the Chesapeake Bay watershed found that SWAT-simulated nitrate loads increased for future climate, but identified six winter cover crop implementation scenarios that have various levels of effectiveness in mitigating nitrate loads (Lee, S. et al., 2017). Renkenberger et al. (2017) applied SWAT in a Maryland watershed and demonstrated that implementations of best management practices (BMPs) designed to meet total maximum daily load (TMDL) targets for current climates would not meet targets in future climates. Yasarer et al. (2017) concluded, using AnnAGNPS in a Mississippi watershed, that sediment and nutrient loads would be expected to increase by $9 \%$ to $12 \%$ with future climate but that no-till and cover-crop conservation practices would decrease loads by $20 \%$ to $75 \%$.

\section{SoIL EROSION}

Soil erosion is a serious, continuing environmental and economic problem of global proportions (Flanagan et al., 2013). One study published in 2017 assessed the wind erosion effects of crop residues and found that the abrasion energy of saltating sand particles was significantly decreased with increasing vegetation density (Gonzales et al., 2017). The remaining articles on soil erosion focused on erosion by water.

\section{MODELING SOIL EROSION AND TRANSPORT}

Several modeling studies of soil erosion were published (table 1). Mittelstet et al. (2017) developed several improvements to the SWAT streambank erosion routine and found the greatest improvement from replacing the empirical effective shear stress equation with a process-based equation. Other studies assessed sediment-yield effects at a range of watershed scales using various models, including AnnAGNPS (Yasarer et al., 2017), APEX (Van Liew et al., 2017), SWAT (Renkenberger et al., 2017; Wallace et al., 2017), and WEPP (Wang, L. et al., 2017).

Methods to develop the erodibility parameter in erosion models were assessed in several studies. Parameters were developed for soil erodibility before and after disturbance by rangeland fire or tree encroachment in RHEM (Al-Hamdan et al., 2017). Parameters were also developed for soil erodibility under native tallgrass prairie and encroaching eastern red cedar using the Jet Erosion Test method compared to standard methods in WEPP and RHEM (Lisenbee et al., 2017). USLE soil erodibility $(K)$ factors were experimentally determined for four soils in Indiana, Missouri, South Dakota, and Vermont, and substantial differences were found among assessments made at dry, pre-wetted then drained, and pre-wetted and saturated conditions (Wu et al., 2017).

\section{Measuring SoIL Erosion}

Several experimental studies of soil erosion were published. A new, low-cost method was developed to estimate raindrop kinetic energy, an important factor affecting soil erosion, and an exponential relationship between rainfall kinetic energy and intensity was derived using experimental data from northwest China (Wang, J. et al., 2017) In a study of soil erodibility in a Kansas crop field having claypan soils, an area with higher crop yield showed an order of magnitude lower critical shear stress (assessed by an erosion function apparatus) than an area having lower crop yield, which was concluded to reveal the extent of historical erosion within the field (Tucker-Kulesza et al., 2017). A study of sediment removal by four surface inlets (that drain ponded agricultural field runoff) found reductions of as much as $66 \%$ for sediment concentration and $23 \%$ for sediment load compared to the standard Hickenbottom inlet (Li, S. et al., 2017). Soil erosion from forest roads was studied by Grace III (2017) and Lang et al. (2017), as described in the Forest Resource Management section. Svendsen et al. (2017) developed a system for tracking military vehicle movements, assessing vegetation disturbance, and translating that information into changes in USLE $\mathrm{C}$ factor.

\section{AGRICULTURAL IRRIGATION}

Global food and water challenges require continued research and development in irrigation engineering and science (Lamm et al., 2016). Dukes et al. (2012) presented seven challenges for irrigation research in this decade:

- Profitable production with declining water supplies.

- Further integration of sensor-based data for real-time autonomous or semi-autonomous management.

- Competition for limited water resources between agriculture and other sectors.

- Impact of declining investment in irrigation research.

- Energy cost and the influence on irrigation type and management.

- Environmental impacts of irrigation.

- Using alternative water sources or degraded water for irrigation.

Collections of irrigation research introduced by Dukes et al. (2012) and Lamm et al. (2016) presented 30 articles on a variety of these topics. In 2017, continuing research was presented on many of these issues, spanning subsurface drip (Lamm and Puig-Bargués, 2017; Lamm and Rogers, 2017), microirrigation (Ju et al., 2017), center pivot (Brar et al., 2017), lateral move (Nörenberg et al., 2017), and surface furrow (Pringle et al., 2017; Bautista and Schlegel, 2017a, 2017b) irrigation systems. 


\section{SUBSURFACE DRIP IRRIGATION}

Subsurface drip irrigation (SDI) system longevity was characterized by testing emitter uniformity on driplines excavated after 27 seasons (26.5 years) and found flow rates within $5 \%$ of original measured values, providing important data for planning SDI amortized costs (Lamm and Rogers, 2017). Another study on SDI systems provided simple, alternative guidelines to the Hazen-Williams equation for sizing SDI flushline diameters (Lamm and Puig-Bargués, 2017). A simple, adaptable analytical approach also was developed and tested for sizing the length of microirrigation laterals on uniformly sloping grounds (Ju et al., 2017).

\section{SURFACE AND SPRINKLER IRRIGATION}

Research on surface and sprinkler irrigation focused on various aspects of system uniformity and efficiency. Residual plant-available soil water (2.4 $\mathrm{m}$ depth) after harvest and prior to planting across western Kansas was greater in irrigated corn than in dryland wheat fields; interestingly, irrigated corn had small (8\% to $22 \%$ ) differences between regions and years but large ( $183 \%$ to $722 \%)$ differences among producers within a region, suggesting that producers could better utilize science-based methods in irrigation scheduling (Lamm et al., 2017). Spatial variability of field capacity and root zone available water capacity in central Nebraska was adequately characterized by identifying a suitable predictor variable (Lo et al., 2017); for the study field, use of elevation, selected on the basis of site-specific knowledge and data, as the predictor variable provided better predictions than deep-soil apparent electrical conductivity. In the Mississippi Delta, furrow-irrigated corn yields and net returns were sensitive to drought stress during tasseling, silking, and pollination, on the basis of measured soil water potential and soil water deficit for multiple irrigation initiation timings on deep silty clay loam soils (Pringle et al., 2017). Bautista and Schlegel developed (2017a) and tested (2017b) software for estimating infiltration and hydraulic resistance parameters in surface furrow irrigation systems, with important benefits for modeling application uniformity. A study of center-pivot irrigation systems in ten Nebraska counties found that energy conservation using variable-frequency drive technology was dependent on elevation difference within the field (Brar et al., 2017); however, the payback period for these systems generally exceeded their economic life. In China's Sanjiang Plain, a geostatistical analysis identified several climate and irrigation system factors that were important to improving irrigation water use efficiency (Fu et al., 2017). Field tests in Rio Grande de Sul, Brazil, were used to develop polynomial equations for estimating lateral-move irrigation system uniformity response to wind speed (Nörenberg et al., 2017). An inventory of on-farm irrigation reservoirs was conducted using remote sensing and on-site inspections as part of a broader effort to assess the current state of water resources in two vulnerable alluvial aquifers in $\mathrm{Ar}$ kansas (Yaeger et al., 2017).

\section{Agricultural Drainage}

Surface and subsurface drainage systems remove excess water from the root zone and have enabled agricultural production on 194 Mha of land globally (Strock et al., 2018). Several studies published in 2017 contribute knowledge on the effects of agricultural drainage. A study in Indiana found that controlled drainage increased water table recession time compared to paired free-drained fields over the nine-year study, indicating that lowering the subsurface drainage outlet before storms could reduce the time at detrimentally high water table levels (Saadat et al., 2017). Skaggs (2017) proposed three key coefficients to quantify and compare hydraulics of drainage systems across sites, soils, and geographic locations: steady subsurface drainage rate, drainage intensity, and drainage coefficient. Jabro et al. (2017) demonstrated that a new automated passive capillary lysimeter accurately monitored real-time drainage water fluxes in the vadose zone over the four-year study period.

A study of drainage and subirrigation systems over 14 years in Missouri found that soybean yields varied with tile spacing and position relative to tile lines, and that narrower tile spacings were more important for reducing yield variability in low-yielding field areas than in high-yielding areas (Nelson, 2017). Subirrigation was more effective in delivering water to the crop in eastern North Dakota and westcentral Minnesota but was less uniform than typical sprinkler and surface-irrigation systems over the two-year evaluation period (Jia et al., 2017).

A field assessment found that the specific electrical conductivity of drainage water in Iowa was not significantly different between growing and non-growing seasons, but it was lower for the soybean year of a corn-soybean rotation than for the corn year of the rotation and for continuous corn or prairie plots; $\mathrm{HCO}_{3}{ }^{-}, \mathrm{Ca}^{2+}$, nitrate, and $\mathrm{Mg}^{2+}$ accounted for 97\% of the bulk electrical conductivity (Zimmerman and Kaleita, 2017b). Additional work by Zimmerman and Kaleita (2017a) found greater concentrations of $\mathrm{HCO}_{3}{ }^{-}, \mathrm{Ca}^{2+}$, and $\mathrm{Mg}^{2+}$ during the post-growing season, greater concentrations of nitrate and $\mathrm{Cl}^{-}$during the growing season, and other interesting relationships among parameters. Dryland barley production in Saskatchewan increased 8-fold and salinity was substantially reduced following installation of a subsurface drainage system enhanced with low-intensity subsurface irrigation and surface roughness barriers to trap snow (Steppuhn and McArthur, 2017). In preparation for future field research on carbon-based, denitrification bioreactors designed to treat intercepted tile drainage in Iowa, Hoover et al. (2017) characterized the hydraulic characteristics of nine pilot-scale bioreactors; they found that the dispersion index was indicative of plug flow, with a residence time of $2.1 \mathrm{~h}$ and hydraulic efficiency of 0.78 (indicative of little shortcircuiting).

\section{Forest RESOURCE MANAGEMENT}

Improved understanding of forest hydrologic and erosion processes is critical for sustainable resource management and to protect the quantity and quality of about $80 \%$ of U.S. freshwater resources (Amatya et al., 2011). Research published in 2017 continued to advance the understanding of forest hydrologic and erosion processes. Srivastava et al. 
(2017) incorporated nonlinear algorithms into WEPP for simulating groundwater baseflow and found improved model performance in simulating daily streamflow volumes and hydrograph recessions in a forested, snowmelt-dominated western Washington watershed. Lang et al. (2017) found that WEPP better simulated soil erosion from 37 forest haul-road stream crossings in Virginia than USLE or RUSLE2, but the time, effort, data, and expertise needed to parameterize and apply WEPP made it impractical to use directly as a forest management tool. Grace III (2017) also studied forest road erosion from 156 runoff-generating events at nine sites in the Appalachian Mountains and found that WEPP adequately simulated sediment yield from the road sections but performed poorly in simulating surface runoff. Muwamba et al. (2017) found that intercropping the bioenergy crop switchgrass into loblolly pine in North Carolina significantly reduced nitrate and phosphate concentrations and phosphorus loads in surface runoff.

\section{LIVESTOCK SYSTEMS}

\section{LAND APPLICATION OF LIVESTOCK MANURE}

Increasing physical separation of crop and livestock production challenges the sustainable distribution of manure nutrients, but county-level analyses in Iowa showed that all but a few counties maintain sufficient cropland capacity to utilize locally produced manure nutrients (Andersen and Pepple, 2017). Nutrient sampling from dairy lagoons in Idaho revealed seasonally higher $\mathrm{N}$ and lower $\mathrm{P}, \mathrm{K}$, total solids, and volatile solids in spring than in fall, and higher concentrations of N, total solids, volatile solids, and chemical oxygen demand (COD) from freestall dairies than from dry-lot dairies, but no influence of dairy size (Leytem et al., 2017). Land application methods and timing also affect runoff water quality; loads of dissolved $\mathrm{P}$, total $\mathrm{P}$, and ammonium-N were significantly less after six weeks than at one to three days after application, and loads of dissolved $\mathrm{P}$ and total $\mathrm{P}$ were less for injection than for broadcast application (Schuster et al., 2017). A setback distance of $12.2 \mathrm{~m}$ on no-till cropland in Nebraska with $7.7 \mathrm{Mg} \mathrm{ha}^{-1}$ residue and 5\% slope was found to reduce runoff concentrations of $\mathrm{N}$, dissolved $\mathrm{P}$, and $\mathrm{K}$, among other constituents, to background levels (Gilley et al., 2017). Biochar added to horse manure or municipal biosolids at $5 \%$ to $8 \%$ (wet basis) improved runoff quality but had significant covariation with runoff curve number (CN) for some parameters (Williams and Edwards, 2017).

\section{EMISSIONS FROM LIVESTOCK SYSTEMS}

Nitrous oxide $\left(\mathrm{NO}_{2}\right)$ is a potent greenhouse gas (almost 300 times greater than $\mathrm{CO}_{2}$ ) with long atmospheric lifetime ( $>100$ years). Emissions from two beef feedlots in Texas were positively related to manure moisture content, temperature, and nitrate concentrations $(\mathrm{p}<0.01)$ and negatively related to organic matter, ammonium, dissolved $\mathrm{C}$, and dissolved $\mathrm{N}$ concentrations $(\mathrm{p}<0.05)$ (Waldrip et al., 2017); $\mathrm{NO}_{2}$ emission predictions based on empirical models developed from these data accurately simulated observed emissions. The traditional non-flow-through chamber methods applied by Waldrip et al. (2017) are labor- and time-inten- sive; Parker et al. (2017) developed and tested new methods using several configurations of a recirculating-flow-through, non-steady-state chamber and produced rapid, precise, and repeatable results. Understanding of $\mathrm{NO}_{2}$ emissions begins with accurate estimation of $\mathrm{N}$ excretion; Martin et al. (2017) characterized the relationship between age and $\mathrm{N}$ excretion as a function of feed consumption and retention for squab broiler, broiler, and roaster chickens and used these relationships to estimate annual and peak daily $\mathrm{N}$ excretion rates in a variety of production operations. Storage of manure increases operational flexibility for manure applications but also can increase greenhouse gas emissions; Holly and Larson (2017) tested several commercial manure additives and biochar, both with and without aeration, and found that none of the studied treatments reduced manure solids or $\mathrm{N}$ emissions.

\section{COMPOSTING AND CARCASS BURIAL}

A process-based model designed to simulate environmental conditions and changes in $\mathrm{C}$ and $\mathrm{N}$ within cattle manure compost windrows was developed and tested (Bonifacio et al., 2017a, 2017b); model agreement with turned-windrow C and $\mathrm{N}$ losses was within $0 \%$ to $2 \%$ after 99 and 188 days, but less agreement was found with static-windrow losses (within $5 \%$ for $\mathrm{C}$ and $12 \%$ for $\mathrm{N}$ after 99 days). Mature compost media used to filter odorous gas emissions from an aerated compost pile of swine manure and chopped cornstalks removed about $98 \%$ of the ammonia, which increased the $\mathrm{N}$ content of the biofilter media by $9 \%$ after four weeks of operation (Tao et al., 2017). In-vessel, aerated, turned composting reduced aqueously extractable estrogens to undetectable levels in three of four municipal biosolid samples, but estrogenicity increased $>6.5$-fold after the first six days in an aqueous extract generated with the remaining sample (Hammett et al., 2017). Measurements beneath and surrounding two carcass burial sites in Saskatchewan at 7 and 60 years post-burial found vertical contaminant movement limited to 1 to $2 \mathrm{~m}$, indicating that burial site-selection characteristics appropriately identified sites with low potential for leachate transport (Pratt and Fonstad, 2017).

\section{NATURAl TREatMent Systems}

Packed-bed, recirculating-filter bioreactors used to treat residential septic tank wastewater removed $94 \%$ of influent ibuprofen, $84 \%$ of naproxen, and $83 \%$ of triclosan (Perez et al., 2017); the researchers also found that $98.6 \%$ to $99.9 \%$ of the organic compound removal was by biodegradation. Colloidal particles from potato farm wastewater were effectively removed by coagulation with two polymers, alum, and ferric chloride; larger volumes of less-expensive alum were needed to achieve target total suspended solids (TSS) levels, and polymers did not require additional chemicals to increase $\mathrm{pH}$ to biologically neutral levels (Bosak et al., 2017).

\section{INTERNATIONAL WATER ISSUES}

Water availability is a global issue with local causes and effects. Limitations in local and regional water availability 
result from factors including overdevelopment, harsh environments, severe aridity, saline water encroachment, technological limitations, and climate variability and change. A study of opportunities and challenges facing treated wastewater reuse found that current natural treatment facilities in the West Bank and secondary treatment technologies in Tunisia could support safe agricultural reuse, but insufficient demand limited utilization of the massive investment in producing high-quality treated wastewaters in Qatar (Dare et al., 2017).

Many tools and technologies for sustainable watershed resource management are relevant to both developing and developed countries. A collection of five articles from the fifth biennial ASABE 21st Century Watershed Technology conference in 2016 highlighted important research with the theme of tools and techniques for sustainability (Tollner and Douglas-Mankin, 2017). A novel fog-catcher system was studied and found to meet a portion $(5 \%)$ of the agricultural irrigation water need in water-deficient Andean communities in Ecuador (Carrera-Villacrés et al., 2017). Another study in Ecuador, also with regional applicability, focused on developing both GIS and multi-criteria based methods to map areas suitable for coffee production, concluding that $50 \%$ of the study area was at least moderately suitable (Ochoa et al., 2017). A new shellfish sanitation model, Mermaid, was demonstrated to be an improvement over the national standard Direct Rule method in making shellfish harvest management decisions that maintain bacterial food safety (Conte and Ahmadi, 2017). Two articles applied the SWAT model to assess the effects of winter cover crops on nitrate loads under future climate conditions in the Chesapeake Bay watershed (Lee, S. et al., 2017) and to support pay-for-performance conservation planning in southeastern Michigan (Muenich et al., 2017).

\section{WATER QUALITY}

While many water quality studies were discussed in other sections, e.g., agricultural drainage (Steppuhn and McArthur, 2017; Zimmerman and Kaleita, 2017a, 2017b), crop modeling (Fang et al., 2017b), climate change (Lee, S. et al., 2017; Renkenberger et al., 2017; Wallace et al., 2017; Yasarer et al., 2017), land application of livestock waste (Gilley et al., 2017; Schuster et al., 2017; Williams and Edwards, 2017), forest resource management (Muwamba et al., 2017), and international watershed technology (Conte and Ahmadi, 2017; Lee, S. et al., 2017; Muenich et al., 2017), additional studies addressed nutrient transport and water quality modeling.

\section{NUTRIENT TRANSPORT}

Total $\mathrm{P}$, dissolved reactive $\mathrm{P}$ (DRP), $\mathrm{Al}$, and $\mathrm{Fe}$ concentrations and loads in runoff over an 11-year study period were detailed in a rotationally grazed pasture site in Georgia (Endale et al., 2017); DRP accounted for $80 \%$ of the total P concentrations and loads, and cattle presence increased concentrations but not loads for DRP and total P, among other results. Heeren et al. (2017) found that flow through macropores and gravel outcrops can allow even a highly sorbing solute to reach alluvial aquifers by studying movement of P (highly sorptive), Rhodamine WT (slightly sorptive), and $\mathrm{Cl}^{-}$(conservative) solutes through silt loam floodplain soils in hay and pasture in northeastern Oklahoma and northwestern Arkansas. Down-furrow movement of nalidixic acid-resistant $E$. coli was reduced by $50 \%$ compared to furrows with no treatment by treating clay soil furrows with alum and grain-dust waste (Abu-Ashour and AlHmoud, 2017). A rapid colorimetric method for determining in-field plant-available soil $\mathrm{P}$ had correlations $>70 \%$ with laboratory test results for four regions in South Korea, and regional differences became non-significant when moisture content and electrical conductivity were included in the multiple regression analysis (Lee, S. Y. et al., 2017).

\section{WATER Quality Modeling}

Several water quality modeling studies were published in 2017 (table 1). A riparian buffer site in North Carolina was the first study to calibrate and validate REMM for plant $\mathrm{N}$ uptake, denitrification, and field-edge $\mathrm{N}$ reductions under conditions of groundwater dilution (Tilak et al., 2017). Van Liew et al. (2017) compared APEX results for streamflow, sediment, $\mathrm{N}$, and $\mathrm{P}$ simulation over a wide range of conditions (including forest, pasture, and crop) at ten USDA Agricultural Research Service watersheds; they found that the APEX model frequently achieved satisfactory performance when fully calibrated, but it rarely provided satisfactory performance when validating the model for different time periods or watersheds. The WEPP-WQ model was enhanced by adding a new overland-flow element for simulating hydrology, soil erosion, and water quality at the hillslope scale and was tested using data from Indiana and Georgia (Wang, L. et al., 2017).

\section{Future ResearCH NEEDS}

The NRES community of ASABE journals strives to make new knowledge accessible to sustain agricultural and natural systems in a changing world. The articles published in 2017 make strides toward that goal, but much more research is needed. Our world is rapidly changing; the past few decades have seen unparalleled changes in the magnitude and distribution of human populations, climate, land resources, and water supplies. At the same time, advances in information technology are allowing collection and distribution of data and knowledge at unprecedented scales and rates. To adapt to our changing world and mitigate adverse effects, researchers are challenged to harness these revolutionary advances in technology to provide new knowledge to enhance the sustainability of agroecosystems while optimizing agroecosystem goods and services. Several areas deserve immediate and sustained research to sustain agricultural and natural systems in a changing world.

\section{Remote Sensing of Agroecosystems}

This review highlighted the use of remote sensing data in only two studies: one to estimate ET using thermal satellite imagery (Büyükcangaz et al., 2017) and the other to inventory irrigation reservoirs (Yaeger et al., 2017). Clearly, many 
more opportunities exist to harness multispectral data from unmanned aerial systems (UASs) and satellite imagery to revolutionize agricultural and natural systems research. Researchers are challenged to increasingly apply remotely sensed data to enhance understanding of spatiotemporal distributions and trends of soil moisture, crop stress, vegetation patterns, land use change, ephemeral gully erosion, stream aggradation and degradation, alluvial channel geomorphological change, pond/lake sedimentation, water quality, pollution plumes, snowpack accumulation, cropland and forest canopy structure, $\mathrm{C}$ dynamics, land resource characteristics, and numerous other agroecosystem properties and processes. UASs should have an increased role in data collection with advances in sensor types, resolution, cost, and weight; improvements in image processing; and customization in scale and frequency of fly-overs to meet specific research objectives. Recent technologies, such as structurefrom-motion (e.g., Westoby et al., 2012), provide highresolution data from low-cost UAS platforms that have yet to be fully utilized in agroecosystems research.

\section{AGROECOSYSTEM RESILIENCY AND VULNERABILITY TO CHANGES IN LAND AND CLIMATE}

Additional research is needed to understand, quantify, and simulate agroecosystem response to ongoing and future changes in land and climate. This review cited many studies that both filled and highlighted research gaps in quantifying and modeling individual soil and crop responses to variable environmental forcings across diverse climatic regions. However, researchers must better quantify the inherent uncertainty in forcings and system response, define the risk of adverse results, and better understand the adaptations and mitigations possible to develop comprehensive vulnerability assessments as well as robust strategies and recommendations for sustaining agroecosystems. Critical challenges include:

- Quantifying agroecosystem response to changing climate, including:

Direct responses: temporal and spatial changes to precipitation, ET, soil water, crop yield, and agroecosystem services as well as longer-term issues of drought, pest and disease infestations, and agroecosystem regime shifts.

Indirect responses: collateral influences of climate change on snowpack and snowmelt magnitude and timing as irrigation source water, trade-offs between surface water and groundwater irrigation sources, and increasing reliance on lower-quality groundwater sources.

- Including crop adaptations (plant breeding, new hybrids, new crops) in relevant models and identifying likely crop shifts considering phenotypic balance (or plasticity) with new local climate.

- Enhancing the knowledge base related to land use adaptations and mitigations, including croplands and grasslands for $\mathrm{C}$ sequestration, emissions from livestock systems, and food-energy-water effects of shifts from food to bioenergy cropping systems and from traditional to enhanced conservation systems.

\section{INTEGRATED MODEls OF AgRoecosysteM \\ SERVICES}

The studies of agroecosystem response to change highlighted in this review typically focused on assessing the effects on crop yields and water quality. Limiting the scope of research to this critical, yet narrow, set of system responses perpetuates a limited view of the goods and services provided by agroecosystems. To provide robust assessments and projections of land resource responses to climate, management, and other stressors, more robust models are needed to incorporate the important interactions, feedbacks, and synergies within the system. Models are needed that adequately capture important goods and services provided by the crops within the agroecosystem boundary as well as important soil-water-air exchanges, interactions with and feedback from wildlife and beneficial insects, and other factors important for robust vulnerability assessments, as discussed in the previous section. Importantly, to fully inform decision-makers, agroecological modelers need to incorporate relevant socio-economic approaches into their integrated systems models.

\section{Water Management in Agricultural Production Systems}

The seven challenges for future agricultural irrigation research presented by Dukes et al. (2012) remain relevant today. These challenges stress the need to enhance research that integrates sensor-based data and management technologies toward achieving sustainability goals of maintaining agroecosystem services (increased production, reduced environmental impacts) while addressing water scarcity at technological (developing alternative water sources, reducing energy costs) and societal (inter-sector competition for water) levels. An excerpt from the recent ASABE drainage collection (Strock et al., 2018) captures the grand challenge for agricultural drainage research as an integrated agroecological and socio-economic issue:

"Perhaps the greatest challenge for drainage system design and management is to reduce downstream impacts due to losses of $N$ and $P$ in drainage outflows. ... As with many water quality issues, the basic problem is that the benefits of applying measures to reduce nutrient losses and improve drainage water quality would be enjoyed and appreciated by society at large, but the costs of applying the practices to provide these benefits would be borne by the producers. Future research must consider drainage system design and management, agronomic management practices, and the role of government and market forces in implementing technical solutions at the scale needed to make a measurable impact. Future emphasis on management of drainage systems should focus on achieving an acceptable balance between agricultural productivity, conservation, and environmental quality."

\section{REPRODUCible Model Results}

This review highlights the extensive efforts underway in modeling agroecosystems. Optimal research efficiency and effectiveness at the global scale can only be achieved with full transparency and reproducibility of published model re- 
sults, allowing researchers to build upon, rather than re-invent, each other's progress. Publication of fully reproducible model results implies providing access to all files and executable code needed to reproduce the modeling research (Saraswat et al., 2015). This will require substantial effort and investment from journals, agencies, and researchers to develop and maintain accessible, quality-assured archives of data, metadata, and model code. Full model reproducibility has numerous benefits as well as some concerns (Saraswat et al., 2015) and will require consistent methods of model calibration, evaluation, and communication (Harmel et al., 2014; Moriasi et al., 2015). Ultimately, however, reproducibility will increase modeling credibility and peer-review quality (Douglas-Mankin et al., 2010; Harmel et al., 2018) and enhance the rate of research progress toward achieving sustainable agricultural and natural systems in a changing world.

\section{CONCLUDING REMARKS}

The NRES community of ASABE journals, Transactions of the ASABE and Applied Engineering in Agriculture, published 98 articles in 2017 covering a broad range of issues in land, water, and agroecosystems research. Experimental and modeling advances were described in hydrology, agroecosystems, climate change effects, soil erosion, irrigation, drainage, forest resource management, livestock systems, natural treatment systems, international water issues, and water quality topic areas. Future research should focus on understanding the processes within and interactions among land, water, and agroecosystems in greater complexity, simulating system processes and interactions with more robust and defensible modeling approaches, and addressing the needs of decision-makers as they affect the sustainability of agroecosystems at local to global scales. Finally, research should make full use of the revolutionary opportunities from remote-sensing data collection and apply these data to enhance understanding of complex land, water, and agroecosystem dynamics.

\section{ACKNOWLEDGEMENTS}

The substantial advancements in human knowledge of land, water, and agroecosystems engineering and science presented in this article were only possible with the creativity, vision, insight, and expertise of many exceptional researchers, the tireless volunteer efforts of many associate editors and reviewers, and the diligent attention of a small, efficient Society staff. Notable among these are invaluable ASABE staff members Pat Howard, Glenn Laing, Peg McCann, Melissa Miller, Sandy Rutter, Robert Smith, and Joe Walker, and a long list of impressive associate editors: Carmen Agouridis, Srinivasulu Ale, Barry Allred, Devendra Amatya, Daniel Andersen, Claire Baffaut, Indrajeet Chaubey, Paul Colaizzi, Kendall DeJonge, Michael Dukes, Garey Fox, John Gilley, Margaret Gitau, Mark Grismer, Daren Harmel, Christopher Hay, Matthew Helmers, Fouad Jaber, Isaya Kisekka, Freddie Lamm, Anna Linhoss, Liwang Ma, Edward Martin, Kati Migliaccio, Debasmita Misra, Aaron
Mittelstet, Kelly Nelson, Jiqin Ni, Prem Parajuli, David Parker, Jaume Puig-Bargués, Zhiming Qi, Gary Sands, Zhuping Sheng, Sanjay Shukla, Jeff Strock, Anita Thompson, Kelly Thorp, Ernest W. Tollner, and Xixi Wang. Any use of trade, product, or firm names in this publication is for descriptive purposes only and does not imply endorsement by the U.S. Government.

\section{REFERENCES}

Abu-Ashour, J., \& Al-Hmoud, N. (2017). Use of alum and grain dust waste for the reduction of bacterial transport on soil surface. Appl. Eng. Agric., 33(1), 91-94. https://doi.org/10.13031/aea.11637

Adhikari, P., Omani, N., Ale, S., DeLaune, P. B., Thorp, K. R., Barnes, E. M., \& Hoogenboom, G. (2017). Simulated effects of winter wheat cover crop on cotton production systems of the Texas Rolling Plains. Trans. ASABE, 60(6), 2083-2096. https://doi.org/10.13031/trans. 12272

Al-Hamdan, O. Z., Pierson, F. B., Nearing, M. A., Williams, C. J., Hernandez, M., Boll, J., ... Spaeth, K. (2017). Developing a parameterization approach for soil erodibility for the Rangeland Hydrology and Erosion Model (RHEM). Trans. ASABE, 60(1), 85-94. https://doi.org/10.13031/trans.11559

Amatya, D. M., Douglas-Mankin, K. R., Williams, T. M., Skaggs, R. W., \& Nettles, J. E. (2011). Advances in forest hydrology: Challenges and opportunities. Trans. ASABE, 54(6), 2049-2056. https://doi.org/10.13031/2013.40672

Amatya, D. M., Irmak, S., Gowda, P., Sun, G., Nettles, J. E., \& Douglas-Mankin, K. R. (2016). Ecosystem evapotranspiration: Challenges in measurements, estimates, and modeling. Trans. ASABE, 59(2), 555-560. https://doi.org/10.13031/trans.59.11808

Anar, M. J., Lin, Z., Ma, L., Bartling, P. N., Teboh, J. M., \& Ostlie, M. (2017). Analysis of parameter sensitivity and identifiability of Root Zone Water Quality Model (RZWQM) for dryland sugarbeet modeling. Trans. ASABE, 60(6), 1995-2010. https://doi.org/10.13031/trans.12313

Andersen, D. S., \& Pepple, L. M. (2017). A county-level assessment of manure nutrient availability relative to crop nutrient capacity in Iowa: Spatial and temporal trends. Trans. ASABE, 60(5), 1669-1680. https://doi.org/10.13031/trans.12417

Araya, A., Kisekka, I., Prasad, P. V. V., Holman, J., Foster, A. J., \& Lollato, R. (2017). Assessing wheat yield, biomass, and water productivity responses to growth stage based irrigation water allocation. Trans. ASABE, 60(1), 107-121. https://doi.org/10.13031/trans.11883

Barnhart, B. L., Sawicz, K. A., Ficklin, D. L., \& Whittaker, G. W. (2017). MOESHA: A genetic algorithm for automatic calibration and estimation of parameter uncertainty and sensitivity of hydrologic models. Trans. ASABE, 60(4), 12591269. https://doi.org/10.13031/trans.12179

Bautista, E., \& Schlegel, J. L. (2017a). A flexible system for estimation of infiltration and hydraulic resistance parameters in surface irrigation. Trans. ASABE, 60(4), 1223-1234. https://doi.org/10.13031/trans.12117

Bautista, E., \& Schlegel, J. L. (2017b). Estimation of infiltration and hydraulic resistance in furrow irrigation, with infiltration dependent on flow depth. Trans. ASABE, 60(6), 1873-1884. https://doi.org/10.13031/trans. 12263

Bonifacio, H. F., Rotz, C. A., \& Richard, T. L. (2017a). A processbased model for cattle manure compost windrows: Part 1. Model description. Trans. ASABE, 60(3), 877-892. https://doi.org/10.13031/trans.12057

Bonifacio, H. F., Rotz, C. A., \& Richard, T. L. (2017b). A processbased model for cattle manure compost windrows: Part 2. Model 
performance and application. Trans. ASABE, 60(3), 893-913. https://doi.org/10.13031/trans. 12058

Bosak, V. K., VanderZaag, A. C., Crolla, A., Kinsley, C., Miller, S. S., Chabot, D., \& Gordon, R. J. (2017). Treatment of potato farm wastewater with coagulation. Appl. Eng. Agric., 33(1), 95101. https://doi.org/10.13031/aea.11609

Brar, D., Kranz, W. L., Lo, T. H., Irmak, S., \& Martin, D. L. (2017). Energy conservation using variable-frequency drives for centerpivot irrigation: Standard systems. Trans. ASABE, 60(1), 95106. https://doi.org/10.13031/trans. 11683

Büyükcangaz, H., Steele, D. D., Tuscherer, S. R., Hopkins, D. G., \& Jia, X. (2017). Evapotranspiration mapping with METRIC to evaluate effectiveness of irrigation in flood mitigation for the Devils Lake basin. Trans. ASABE, 60(5), 1575-1591. https://doi.org/10.13031/trans.12149

Carrera-Villacrés, D. V., Robalino, I. C., Rodriguez, F. F., Sandoval, W. R., Hidalgo, D. L., \& Toulkeridis, T. (2017). An innovative fog catcher system applied in the Andean communities of Ecuador. Trans. ASABE, 60(6), 1917-1923. https://doi.org/10.13031/trans.12368

Chaubey, I., Bosch, D. D., Muñoz-Carpena, R., Daren Harmel, R., Douglas-Mankin, K. R., Nejadhashemi, A. P., ... Shirmohammadi, A. (2016). Climate change: A call for adaptation and mitigation strategies. Trans. ASABE, 59(6), 17091713. https://doi.org/10.13031/trans.59.12138

Conte, F. S., \& Ahmadi, A. (2017). Mermaid: A shellfish sanitation model providing additional metrics for the classification of shellfish growing areas of Virginia (USA), Managed by the direct rule method. Appl. Eng. Agric., 33(6), 825-839. https://doi.org/10.13031/aea.12355

Dare, A. E., Mohtar, R. H., Jafvert, C. T., Shomar, B., Engel, B., Boukchina, R., \& Rabi, A. (2017). Opportunities and challenges for treated wastewater reuse in the West Bank, Tunisia, and Qatar. Trans. ASABE, 60(5), 1563-1574. https://doi.org/10.13031/trans.12109

DeJonge, K. C., \& Thorp, K. R. (2017). Implementing standardized reference evapotranspiration and dual crop coefficient approach in the DSSAT cropping system model. Trans. ASABE, 60(6), 1965-1981. https://doi.org/10.13031/trans.12321

Douglas-Mankin, K. R., Srinivasan, R., \& Arnold, J. G. (2010). Soil and Water Assessment Tool (SWAT) model: Current developments and applications. Trans. ASABE, 53(5), 14231431. https://doi.org/10.13031/2013.34915

Dukes, M. D., Bjorneberg, D. L., \& Klocke, N. L. (2012). Advances in irrigation: Select works from the 2010 Decennial Irrigation Symposium. Trans. ASABE, 55(2), 477-482. https://doi.org/10.13031/2013.41398

Duncan, E. W., Kleinman, P. J., Folmar, G. J., Saporito, L. S., Feyereisen, G. W., Buda, A. R., ... Beegle, D. B. (2017). Development of field-scale lysimeters to assess management impacts on runoff. Trans. ASABE, 60(2), 419-429. https://doi.org/10.13031/trans.11901

Endale, D. M., Schomberg, H. H., Fisher, D. S., Owens, L. B., Jenkins, M. B., \& Bonta, J. V. (2017). Phosphorus, iron, and aluminum losses in runoff from a rotationally grazed pasture in Georgia. Trans. ASABE, 60(3), 861-875. https://doi.org/10.13031/trans.12053

Espadafor, M., Couto, L., Resende, M., Henderson, D. W., GarciaVila, M., \& Fereres, E. (2017). Simulation of the responses of dry beans (Phaseolus vulgaris L.) to irrigation. Trans. ASABE, 60(6), 1983-1994. https://doi.org/10.13031/trans.12386

Fang, Q., Ma, L., Qi, Z., Shen, Y., He, L., Xu, S., ... Yu, Q. (2017a). Optimizing ET-based irrigation scheduling for wheat and maize with water constraints. Trans. ASABE, 60(6), 2053-2065. https://doi.org/10.13031/trans.12363

Fang, Q., Ma, L., Trout, T. J., Comas, L. H., DeJonge, K. C., Ahuja,
L. R., ... Malone, R. W. (2017b). Modeling N concentration and uptake for maize hybrids under growth stage-based deficit irrigations. Trans. ASABE, 60(6), 2067-2081.

https://doi.org/10.13031/trans.12405

Feng, Q., Chaubey, I., Cibin, R., Engel, B., Sudheer, K. P., \& Volenec, J. (2017). Simulating establishment periods of switchgrass and Miscanthus in the Soil and Water Assessment Tool (SWAT). Trans. ASABE, 60(5), 1621-1632. https://doi.org/10.13031/trans.12227

Flanagan, D. C., Ascough II, J. C., Nieber, J. L., Misra, D., \& Douglas-Mankin, K. R. (2013). Advances in soil erosion research: Processes, measurement, and modeling. Trans. ASABE, 56(2), 455-463. https://doi.org/10.13031/2013.42666

Fu, Q., Liu, W., Cui, S., Li, T., \& Liu, D. (2017). Geostatistical analysis of factors affecting irrigation water use efficiency on the Sanjiang Plain. Trans. ASABE, 60(2), 431-438. https://doi.org/10.13031/trans.11984

Gilley, J. E., Bartelt-Hunt, S. L., Eskridge, K. M., Li, X., Schmidt, A. M., \& Snow, D. D. (2017). Setback distance requirements for removal of swine slurry constituents in runoff. Trans. ASABE, 60(6), 1885-1894. https://doi.org/10.13031/trans.12310

Gonzales, H. B., Casada, M. E., Hagen, L. J., Tatarko, J., \& Maghirang, R. G. (2017). Sand transport and abrasion within simulated standing vegetation. Trans. ASABE, 60(3), 791-802. https://doi.org/10.13031/trans.11878

Grace III, J. M. (2017). Predicting forest road surface erosion and storm runoff from high-elevation sites. Trans. ASABE, 60(3), 705-719. https://doi.org/10.13031/trans.11646

Hammett, K. M., Felton, G. K., Fisher, D. J., Yonkos, L. T., Mullin, E. J., \& Aga, D. S. (2017). Integrated assessment of aqueously extractable estrogens in municipal biosolids after pilot-scale composting. Trans. ASABE, 60(5), 1645-1658. https://doi.org/10.13031/trans.12241

Harmel, R. D., Baffaut, C., \& Douglas-Mankin, K. R. (2018). Review and Development of ASABE Engineering Practice 621: Guidelines for calibrating, validating, and evaluating hydrologic and water quality models. Trans. ASABE, 61(4), 1393-1401. https://doi.org/10.13031/trans.12806

Harmel, R. D., Smith, P. K., Migliaccio, K. W., Chaubey, I., Douglas-Mankin, K. R., Benham, B., ... Robson, B. J. (2014). Evaluating, interpreting, and communicating performance of hydrologic/water quality models considering intended use: A review and recommendations. Environ. Model. Software, 57, 4051. https://doi.org/10.1016/j.envsoft.2014.02.013

Heeren, D. M., Fox, G. A., Penn, C. J., Halihan, T., Storm, D. E., \& Haggard, B. E. (2017). Impact of macropores and gravel outcrops on phosphorus leaching at the plot scale in silt loam soils. Trans. ASABE, 60(3), 823-835. https://doi.org/10.13031/trans.12015

Holly, M. A., \& Larson, R. A. (2017). Effects of manure storage additives on manure composition and greenhouse gas and ammonia emissions. Trans. ASABE, 60(2), 449-456. https://doi.org/10.13031/trans.12066

Hoover, N. L., Soupir, M. L., VanDePol, R. D., Goode, T. R., \& Law, J. Y. (2017). Pilot-scale denitrification bioreactors for replicated field research. Appl. Eng. Agric., 33(1), 83-90. https://doi.org/10.13031/aea.11736

Jabro, J. D., Iversen, W. M., Stevens, W. B., Allen, B. L., \& Sainju, U. M. (2017). A new automated passive capillary lysimeter for logging real-time drainage water fluxes. Appl. Eng. Agric., 33(6), 849-857. https://doi.org/10.13031/aea.12433

Jia, X., Scherer, T. F., Steele, D. D., \& DeSutter, T. M. (2017). Subirrigation system performance and evaluation in the Red River Valley of the North. Appl. Eng. Agric., 33(6), 811-818. https://doi.org/10.13031/aea.12286

Joshi, N., Singh, A. K., \& Madramootoo, C. A. (2017). Application 
of DSSAT model to simulate corn yield under long-term tillage and residue practices. Trans. ASABE, 60(1), 67-83.

https://doi.org/10.13031/trans.11545

Ju, X., Wu, P., Weckler, P. R., \& Zhu, D. (2017). Simplified approach for designing length of microirrigation laterals. Appl. Eng. Agric., 33(1), 75-82. https://doi.org/10.13031/aea.11882

Kisekka, I., DeJonge, K. C., Ma, L., Paz, J., \& Douglas-Mankin, K. (2017). Crop modeling applications in agricultural water management. Trans. ASABE, 60(6), 1959-1964. https://doi.org/10.13031/trans.12693

Kukal, M. S., \& Irmak, S. (2017). Spatial and temporal changes in maize and soybean grain yield, precipitation use efficiency, and crop water productivity in the U.S. Great Plains. Trans. ASABE, 60(4), 1189-1208. https://doi.org/10.13031/trans.12072

Lamm, F. R., \& Puig-Bargués, J. (2017). Simplified equations to estimate flushline diameter for subsurface drip irrigation systems. Trans. ASABE, 60(1), 185-192.

https://doi.org/10.13031/trans.12131

Lamm, F. R., \& Rogers, D. H. (2017). Longevity and performance of a subsurface drip irrigation system. Trans. ASABE, 60(3), 931-939. https://doi.org/10.13031/trans.12237

Lamm, F. R., Rogers, D. H., Schlegel, A. J., Lin, X., Aiken, R. M., Klocke, N. L., ... Shaw, L. K. (2017). Trends in plant-available soil water on producer fields of western Kansas. Appl. Eng. Agric., 33(6), 859-868. https://doi.org/10.13031/aea.12452

Lamm, F. R., Stone, K. C., Dukes, M. D., Howell Sr., T. A., Robbins Jr., J. W., \& Mecham, B. Q. (2016). Emerging technologies for sustainable irrigation: Selected papers from the 2015 ASABE and IA Irrigation Symposium. Trans. ASABE, 59(1), 155-161. https://doi.org/10.13031/trans.59.11706

Lang, A. J., Aust, W. M., Bolding, M. C., McGuire, K. J., \& Schilling, E. B. (2017). Comparing sediment trap data with erosion models for evaluation of forest haul road stream crossing approaches. Trans. ASABE, 60(2), 393-408.

https://doi.org/10.13031/trans.11859

Lee, S. Y., Park, H. J., Han, C. W., Lee, S. Y., \& Kweon, G. Y. (2017). Validation of a rapid colorimetric method with field soils. Trans. ASABE, 60(4), 1271-1278. https://doi.org/10.13031/trans.12204

Lee, S., Sadeghi, A. M., Yeo, I.-Y., McCarty, G. W., \& Hively, W. D. (2017). Assessing the impacts of future climate conditions on the effectiveness of winter cover crops in reducing nitrate loads into the Chesapeake Bay watersheds using the SWAT model. Trans. ASABE, 60(6), 1939-1955. https://doi.org/10.13031/trans.12390

Leytem, A. B., Dungan, R. S., \& Bjorneberg, D. L. (2017). Spatial and temporal variation in physicochemical properties of dairy lagoons in south-central Idaho. Trans. ASABE, 60(2), 439-447. https://doi.org/10.13031/trans.11991

Li, M., Liu, Y., Yan, H., \& Sui, R. (2017). Effects of irrigation amount on alfalfa yield and quality with a center-pivot system. Trans. ASABE, 60(5), 1633-1644. https://doi.org/10.13031/trans.12239

Li, S., Bhattarai, R., Cooke, R. A., Rendall, T., Dahal, V., \& Kalita, P. K. (2017). Assessment of surface inlets performance on sediment transport to subsurface drainage system. Appl. Eng. Agric., 33(2), 217-224. https://doi.org/10.13031/aea.12039

Linhoss, A. C., Tagert, M. L., Buka, H., \& Sassenrath, G. (2017). Factors affecting model sensitivity and uncertainty: Application to an irrigation scheduler. Trans. ASABE, 60(3), 803-812. https://doi.org/10.13031/trans.11912

Linker, R., \& Kisekka, I. (2017). Model-based deficit irrigation of maize in Kansas. Trans. ASABE, 60(6), 2011-2022. https://doi.org/10.13031/trans.12341

Lisenbee, W. A., Fox, G. A., Saenz, A. A., \& Miller, R. B. (2017). Comparison of field jet erosion tests and WEPP-predicted erodibility parameters for varying land cover. Trans. $A S A B E$, 60(1), 173-184. https://doi.org/10.13031/trans.12012

Liu, C., Qi, Z., Gu, Z., Gui, D., \& Zeng, F. (2017). Optimizing irrigation rates for cotton production in an extremely arid area using RZWQM2-simulated water stress. Trans. ASABE, 60(6), 2041-2052. https://doi.org/10.13031/trans. 12365

Lo, T. H., Heeren, D. M., Mateos, L., Luck, J. D., Martin, D. L., Miller, K. A., ... Shaver, T. M. (2017). Field characterization of field capacity and root zone available water capacity for variable rate irrigation. Appl. Eng. Agric., 33(4), 559-572. https://doi.org/10.13031/aea.11963

Marek, G. W., Marek, T. H., Xue, Q., Gowda, P. H., Evett, S. R., \& Brauer, D. K. (2017). Simulating evapotranspiration and yield response of selected corn varieties under full and limited irrigation in the Texas High Plains using DSSAT-CERESmaize. Trans. ASABE, 60(3), 837-846. https://doi.org/10.13031/trans. 12048

Martin Jr., J. H., Swaney, D. P., \& Greene, D. B. (2017). Comparison of estimates of nitrogen excretion by squab broilers, broilers, and roasters: Implications for ammonia emissions. Trans. ASABE, 60(3), 783-789. https://doi.org/10.13031/trans.11746

McDaniel, R. L., Munster, C., \& Cothren, J. T. (2017a). Crop and location specific agricultural drought quantification: Part I. Method development. Trans. ASABE, 60(3), 721-728. https://doi.org/10.13031/trans.11649

McDaniel, R. L., Munster, C., \& Cothren, J. T. (2017b). Crop and location specific agricultural drought quantification: Part II. Case study. Trans. ASABE, 60(3), 729-739. https://doi.org/10.13031/trans.11650

McDaniel, R. L., Munster, C., \& Nielsen-Gammon, J. (2017c). Crop and location specific agricultural drought quantification: Part III. Forecasting water stress and yield trends. Trans. ASABE, 60(3), 741-752. https://doi.org/10.13031/trans.11651

Mishra, N., Srivastava, P., \& Singh, S. (2017). What do climate change projections say about future droughts in Alabama and Georgia? Trans. ASABE, 60(4), 1139-1151. https://doi.org/10.13031/trans.11854

Mittelstet, A. R., Storm, D. E., Fox, G. A., \& Allen, P. M. (2017). Modeling streambank erosion on composite streambanks on a watershed scale. Trans. ASABE, 60(3), 753-767. https://doi.org/10.13031/trans.11666

Moriasi, D. N., Wilson, B. N., Douglas-Mankin, K. R., Arnold, J. G., \& Gowda, P. H. (2012). Hydrologic and water quality models: Use, calibration, and validation. Trans. ASABE, 55(4), 1241-1247. https://doi.org/10.13031/2013.42265

Moriasi, D. N., Zeckoski, R. W., Arnold, J. G., Baffaut, C., Malone, R. W., Daggupati, P., ... Douglas-Mankin, K. R. (2015). Hydrologic and water quality models: Key calibration and validation topics. Trans. ASABE, 58(6), 1609-1618. https://doi.org/10.13031/trans.58.11075

Muenich, R. L., Kalcic, M. M., Winsten, J., Fisher, K., Day, M., O’Neil, G., ... Scavia, D. (2017). Pay-for-performance conservation using SWAT highlights need for field-level agricultural conservation. Trans. ASABE, 60(6), 1925-1937. https://doi.org/10.13031/trans.12379

Muñoz-Carpena, R., Vellidis, G., Shirmohammadi, A., \& Wallender, W. W. (2006). Evaluation of modeling tools for TMDL development and implementation. Trans. ASABE, 49(4), 961-965. https://doi.org/10.13031/2013.21747

Muwamba, A., Amatya, D. M., Chescheir, G. M., Nettles, J. E., Appelboom, T., Ssegane, H., ... Tian, S. (2017). Water quality effects of switchgrass intercropping on pine forest in coastal North Carolina. Trans. ASABE, 60(5), 1607-1620. https://doi.org/10.13031/trans.12181

Nelson, K. A. (2017). Soybean yield variability of drainage and 
subirrigation systems in a claypan soil. Appl. Eng. Agric., 33(6), 801-809. https://doi.org/10.13031/aea.12276

Nörenberg, B. G., Faria, L. C., Rettore Neto, O., Beskow, S., Colombo, A., Timm, L. C., \& Manke, E. B. (2017). Wind speed and direction on water application uniformity of a mechanical lateral-move irrigation system. Appl. Eng. Agric., 33(4), 543549. https://doi.org/10.13031/aea.12244

Ochoa, P. A., Chamba, Y. M., Arteaga, J. G., \& Capa, E. D. (2017). Estimation of suitable areas for coffee growth using a GIS approach and multicriteria evaluation in regions with scarce data. Appl. Eng. Agric., 33(6), 841-848.

https://doi.org/10.13031/aea.12354

Parker, D. B., Casey, K. D., Todd, R. W., Waldrip, H. M., Marek, G. M., Auvermann, B. W., ... Meyer, B. (2017). Improved chamber systems for rapid, real-time nitrous oxide emissions from manure and soil. Trans. ASABE, 60(4), 1235-1258. https://doi.org/10.13031/trans.12151

Perez, B. N., Buchanan, J. R., DeBruyn, J. M., Cobaugh, K., \& Hart, W. E. (2017). Removal of ibuprofen, naproxen, and triclosan from domestic wastewater using recirculating packedbed media filters. Trans. ASABE, 60(5), 1593-1605. https://doi.org/10.13031/trans.12176

Pratt, D. L., \& Fonstad, T. A. (2017). Geochemical evolution and leachate transport beneath two carcass burial sites: A field investigation. Trans. ASABE, 60(6), 1895-1911. https://doi.org/10.13031/trans.12476

Pringle III, H. C., Falconer, L. L., Fisher, D. K., \& Krutz, L. J. (2017). Initiation of furrow irrigation in corn on a Dundee/Forestdale silty clay loam soil with and without deep tillage. Appl. Eng. Agric., 33(2), 205-216. https://doi.org/10.13031/aea.12050

Rasche, L., \& Taylor, R. A. (2017). A generic pest submodel for use in integrated assessment models. Trans. ASABE, 60(1), 147-158. https://doi.org/10.13031/trans.11931

Renkenberger, J., Montas, H., Leisnham, P. T., Chanse, V., Shirmohammadi, A., Sadeghi, A., ... Lansing, D. (2017). Effectiveness of best management practices with changing climate in a Maryland watershed. Trans. ASABE, 60(3), 769782. https://doi.org/10.13031/trans.11691

Rodriguez, D., Reca, J., Martinez, J., \& Urrestarazu, M. (2017). Automatic irrigation control system for soilless culture based on feedback from drainage hydrograph. Appl. Eng. Agric., 33(4), 531-542. https://doi.org/10.13031/aea.11172

Saadat, S., Bowling, L., Frankenberger, J., \& Brooks, K. (2017). Effects of controlled drainage on water table recession rate. Trans. ASABE, 60(3), 813-821. https://doi.org/10.13031/trans.11922

Saraswat, D., R. Frankenberg, J., Pai, N., Ale, S., Daggupati, P., R. Douglas-Mankin, K., \& A. Youssef, M. (2015). Hydrologic and water quality models: Documentation and reporting procedures for calibration, validation, and use. Trans. ASABE, 58(6), 17871797. https://doi.org/10.13031/trans.58.10707

Schuster, N. R., Bartelt-Hunt, S. L., Durso, L. M., Gilley, J. E., Li, X., Marx, D. B., ... Snow, D. D. (2017). Runoff water quality characteristics following swine slurry application under broadcast and injected conditions. Trans. ASABE, 60(1), 53-66. https://doi.org/10.13031/trans.11370

Sharda, V., Handyside, C., Chaves, B., McNider, R. T., \& Hoogenboom, G. (2017). The impact of spatial soil variability on simulation of regional maize yield. Trans. ASABE, 60(6), 2137-2148. https://doi.org/10.13031/trans.12374

Skaggs, R. W. (2017). Coefficients for quantifying subsurface drainage rates. Appl. Eng. Agric., 33(6), 793-799. https://doi.org/10.13031/aea.12302

Srivastava, A., Wu, J. Q., Elliot, W. J., Brooks, E. S., \& Flanagan, D. C. (2017). Modeling streamflow in a snow-dominated forest watershed using the Water Erosion Prediction Project (WEPP) model. Trans. ASABE, 60(4), 1171-1187.

https://doi.org/10.13031/trans.12035

Steppuhn, H., \& McArthur, L. J. (2017). Enhancing subsurface drainage to control salinity in dryland agriculture. Appl. Eng. Agric., 33(6), 819-824. https://doi.org/10.13031/aea.12252

Strock, J. S., Hay, C., Helmers, M. J., Nelson, K. A., Sands, G. R., Skaggs, R. W., \& Douglas-Mankin, K. R. (2018). Advances in drainage: Selected works from the 10th International Drainage Symposium. Trans. ASABE, 61(1), 161-168. https://doi.org/10.13031/trans.12668

Svendsen, N. G., Koch, D. J., Gertner, G. Z., Howard, H. R., \& Ayers, P. D. (2017). Vehicle impact analysis using vehicle tracking systems on military lands. Trans. ASABE, 60(6), 18651872. https://doi.org/10.13031/trans.12133

Tang, Q., Feng, G., Fisher, D., Zhang, H., Ouyang, Y., Adeli, A., \& Jenkins, J. (2018). Rain water deficit and irrigation demand of major row crops in the Mississippi Delta. Trans. ASABE, 61(3), 927-935. https://doi.org/10.13031/trans.12397

Tao, X., Shang, B., Dong, H., \& Chen, Y. (2017). A field-scale evaluation of compost biofiltration of ammonia volatilized from swine manure composting in a forced-aeration system. Trans. ASABE, 60(2), 369-375. https://doi.org/10.13031/trans.11266

Tatsumi, K. (2017). Integrated assessment of climate change impacts on corn yield in the U.S. using a crop model. Trans. ASABE, 60(6), 2123-2136. https://doi.org/10.13031/trans.12314

Thorp, K. R., Hunsaker, D. J., Bronson, K. F., Andrade-Sanchez, P., \& Barnes, E. M. (2017). Cotton irrigation scheduling using a crop growth model and FAO-56 methods: Field and simulation studies. Trans. ASABE, 60(6), 2023-2039. https://doi.org/10.13031/trans.12323

Tilak, A. S., Youssef, M. A., Burchell II, M. R., Lowrance, R. R., \& Williams, R. G. (2017). Testing the Riparian Ecosystem Management Model (REMM) on a riparian buffer with dilution from deep groundwater. Trans. ASABE, 60(2), 377-392. https://doi.org/10.13031/trans.11832

Tollner, E. W., \& Douglas-Mankin, K. R. (2017). International watershed technology: Improving water quality and quantity at the local, basin, and regional scales. Trans. ASABE, 60(6), 19151916. https://doi.org/10.13031/trans.12687

Tucker-Kulesza, S. E., Sassenrath, G. F., Tran, T., Koehn, W., \& Erickson, L. (2017). Site-specific erodibility in claypan soils: Dependence on subsoil characteristics. Appl. Eng. Agric., 33(5), 705-718. https://doi.org/10.13031/aea.12120

Tuppad, P., Douglas-Mankin, K. R., Lee, T., Srinivasan, R., \& Arnold, J. G. (2011). Soil and Water Assessment Tool (SWAT) hydrologic/water quality model: Extended capability and wider adoption. Trans. ASABE, 54(5), 1677-1684. https://doi.org/10.13031/2013.39856

Van Liew, M. W., Wortmann, C. S., Moriasi, D. N., King, K. W., Flanagan, D. C., Veith, T. L., ... Tomer, M. D. (2017).

Evaluating the APEX model for simulating streamflow and water quality on ten agricultural watersheds in the U.S. Trans. ASABE, 60(1), 123-146. https://doi.org/10.13031/trans.11903

Waldrip, H. M., Casey, K. D., Todd, R. W., \& Parker, D. B. (2017). Nitrous oxide emissions from Southern High Plains beef cattle feedyards: Measurement and modeling. Trans. ASABE, 60(4), 1209-1221. https://doi.org/10.13031/trans.12085

Wallace, C. W., Flanagan, D. C., \& Engel, B. A. (2017). Quantifying the effects of future climate conditions on runoff, sediment, and chemical losses at different watershed sizes. Trans. ASABE, 60(3), 915-929. https://doi.org/10.13031/trans.12094

Wang, J., Watts, D. B., Meng, Q., Way, T. R., \& Zhang, Q. (2017). Estimating raindrop kinetic energy: Evaluation of a low-cost method. Appl. Eng. Agric., 33(4), 551-558. 
https://doi.org/10.13031/aea.11518

Wang, L., Flanagan, D. C., \& Cherkauer, K. A. (2017). Development of a coupled water quality model. Trans. ASABE, 60(4), 1153-1170. https://doi.org/10.13031/trans.12002

Westoby, M. J., Brasington, J., Glasser, N. F., Hambrey, M. J., \& Reynolds, J. M. (2012). 'Structure-from-Motion' photogrammetry: A low-cost, effective tool for geoscience applications. Geomorphology, 179, 300-314. https://doi.org/10.1016/j.geomorph.2012.08.021

Whitbread, A. M., Hoffmann, M. P., Davoren, C. W., Mowat, D., \& Baldock, J. A. (2017). Measuring and modeling the water balance in low-rainfall cropping systems. Trans. ASABE, 60(6), 2097-2110. https://doi.org/10.13031/trans.12581

Wibowo, R. P., Hendricks, N. P., Kisekka, I., \& Araya, A. (2017). Using a crop simulation model to understand the impact of risk aversion on optimal irrigation management. Trans. ASABE, 60(6), 2111-2122. https://doi.org/10.13031/trans.12320

Williams, R. E., \& Edwards, D. R. (2017). Effects of biochar treatment of municipal biosolids and horse manure on quality of runoff from fescue plots. Trans. ASABE, 60(2), 409-417. https://doi.org/10.13031/trans.11891

Wu, Q., Flanagan, D. C., Huang, C.-h., \& Wu, F. (2017). Estimation of USLE K values with a process-based approach.
Trans. ASABE, 60(1), 159-172.

https://doi.org/10.13031/trans.11948

Yaeger, M. A., Reba, M. L., Massey, J. H., \& Adviento-Borbe, M. A. (2017). On-farm irrigation reservoirs in two Arkansas critical groundwater regions: A comparative inventory. Appl. Eng. Agric., 33(6), 869-878. https://doi.org/10.13031/aea.12352

Yasarer, L. M., Bingner, R. L., Garbrecht, J. D., Locke, M. A., Lizotte Jr., R. E., Momm, H. G., \& Busteed, P. R. (2017). Climate change impacts on runoff, sediment, and nutrient loads in an agricultural watershed in the lower Mississippi River basin. Appl. Eng. Agric., 33(3), 379-392. https://doi.org/10.13031/aea.12047

Zhao, W., Li, J., Yang, R., \& Li, Y. (2017). Crop yield and water productivity responses in management zones for variable-rate irrigation based on available soil water holding capacity. Trans. $A S A B E$, 60(5), 1659-1667. https://doi.org/10.13031/trans.12340

Zimmerman, B. A., \& Kaleita, A. L. (2017a). Dissolved constituents in agricultural drainage waters. Trans. $A S A B E$, 60(3), 847-859. https://doi.org/10.13031/trans.12051

Zimmerman, B. A., \& Kaleita, A. L. (2017b). Electrical conductivity of agricultural drainage water in Iowa. Appl. Eng. Agric., 33(3), 369-378. https://doi.org/10.13031/aea.12040 